\title{
STUDY REGARDING THE DETERMINATION OF VALPROIC ACID SERUM LEVELS BY EMIT
}

\author{
MIHAIL SILVIU TUDOSIE ${ }^{1 \#}$, GENICA CARAGEA ${ }^{2}$, ILEANA DANESCU ${ }^{2}$, CATALIN-GABRIEL $^{-}$ \\ SMARANDACHE ${ }^{1 \#}$, ANA MARIA DASCALU $^{1 \#}$, ANDREEA-MARIA SMARANDACHE $^{1}$, BOGDAN $^{2}$ \\ SOCEA $^{1}$, DRAGOS MARIAN POPESCU ${ }^{3}$, SILVIU MIREL PITURU ${ }^{1}$, RADU VIRGIL COSTEA ${ }^{1 *}$, \\ RADU MACOVEI ${ }^{1,2}$, DRAGOS SERBAN ${ }^{1}$
}

1 "Carol Davila" University of Medicine and Pharmacy Bucharest, Romania

${ }^{2}$ Intensive Care Unit of the Emergencies Clinical Hospital Bucharest, Romania

${ }^{3}$ University of Medicine and Pharmacy Craiova, Romania

*corresponding author: radu.costea@umfcd.ro

${ }^{\#}$ Authors with equal contribution.

\begin{abstract}
Valproic acid (n-dipropylacetic acid) is a unique anticonvulsant due to its structure, used in treating anxiety, alcoholism and mood disorders. At therapeutic doses, valproic acid half-life varies from 10 to 20 hours in adults, while it is significantly shorter (6 to 9 hours) in children. It is metabolized at hepatic level into several metabolites of which two in larger quantities, namely 2-en-VPA (2-propyl-2-pentenoic acid) and 3-keto VPA (2-propyl-3-keto-pentanoic acid) which form as a result of a beta hepatic microsomal oxidation. These two metabolites can be identified in urine in proportion of $70 \%$. In case of an overdose or of longterm treatment, high serum levels of hepatic enzymes and hyperammonaemia may appear. A less frequent side effect is acute pancreatitis, with high serum amylase. The plasma concentration of VPA higher than $100 \mathrm{mg} / \mathrm{L}$ is concerning and a concentration higher than $450 \mathrm{mg} / \mathrm{L}$ is associated with a moderate or severe prognostic, although there is no tight correlation between plasma levels of VPA and the severity of clinical signs. Immunochemical methods use a specific antibody for the tested molecule and a marked form of the same compounds. There are two main ways to quantify the reaction: homogenous phase method and heterogeneous phase method. The homogenous methods, faster and completely automized are: EMIT (Enzyme Multiplied Immunoassay Technique) and FPIA (Fluorescence Polarization Immunoassay Technique). In the EMIT method, the marking is made through an enzyme by binding the antibody to the labelled enzyme molecule and this method can be applied confidently to determine the serum levels of valproic acid. Also, it is useful both in monitoring valproic acid treatment and, especially, in establishing a certain diagnosis in acute mono or multidrug acute intoxications.
\end{abstract}

\section{Rezumat}

Acidul valproic (acid n-dipropilacetic) este un anticonvulsivant unic datorită structurii sale, utilizat în tratarea anxietății, alcoolismului și tulburărilor de dispoziție. La doze terapeutice, timpul de înjumătăţire al acidului valproic variază de la 10 la 20 de ore la adulți, în timp ce la copii este semnificativ mai scurt (6 până la 9 ore). Este metabolizat la nivel hepatic în mai mulți metaboliți dintre care doi în cantități mai mari, și anume 2-en-VPA (acid 2-propil-2-pentenoic) și 3-ceto VPA (acid 2-propil-3ceto-pentanoic) care se formează ca urmare a unei beta-oxidări microzomale hepatice. Acești doi metaboliți pot fi identificați în urină în proporție de 70\%. În caz de supradozaj sau de tratament de lungă durată, pot apărea niveluri serice ridicate ale enzimelor hepatice și hiperamoniemie. Un efect secundar mai puțin frecvent este pancreatita acută, cu amilază serică ridicată. Concentrația plasmatică a VPA mai mare de $100 \mathrm{mg} / \mathrm{L}$ este potențial toxică, iar o concentrație mai mare de $450 \mathrm{mg} / \mathrm{L}$ este asociată cu un prognostic moderat sau sever, deși nu există o corelație strânsă între nivelurile plasmatice ale VPA și severitatea semnelor clinice. Metodele imunochimice folosesc un anticorp specific pentru molecula testată și o formă marcată a acelorași compuși. Există două moduri principale de cuantificare a reacției: metoda fazei omogene și metoda fazei eterogene. Metodele omogene, mai rapide și complet automatizate sunt: EMIT (Enzyme Multiplied Immunoassay Technique) și FPIA (Fluorescence Polarization Immunoassay Technique). În metoda EMIT, marcarea se face cu ajutorul unei enzime, prin legarea anticorpului la molecula enzimelor marcate și poate fi aplicată cu încredere pentru a determina nivelurile serice ale acidului valproic. De asemenea, este utilă atât în monitorizarea tratamentului cu acid valproic, cât mai ales în stabilirea unui anumit diagnostic în intoxicaţii acute mono sau multidrug.

Keywords: valproic acid, serum levels, acute intoxications, acute pancreatitis

\section{Introduction}

Valproic acid (n-dipropylacetic acid) is a unique anticonvulsant due to its structure, used in treating epileptic crises, anxiety, alcoholism and maniacal episodes ("bipolar disorder"). At therapeutic doses, valproic acid half-life varies from 10 to 20 hours in adults, while it is significantly shorter (6 to 9 hours) in children. Bioavailability is reported to be approximately $90 \%$ 
for all oral formulations with enteric-coated forms possibly reaching $100 \%$ [30]. The anticonvulsant mechanism of action of valproic acid seems to be the cerebral increase of GABA, especially within the grey matter of the brain, which is involved in controlling and propagating convulsions $[3,13]$. The mechanism of action of valproic acid is still unclear, but it is assumed that while cerebral concentrations of gamma aminobutiric acid (GABA) increase, a decrease of monophosphate cyclic guanosine monophosphate is recorded (CGMP) [24].

It is metabolized at hepatic level into several metabolites of which two in larger quantities, namely 2-en-VPA (2propyl-2-pentenoic acid) and 3-keto VPA (2-propyl3-keto-pentanoic acid) which form as a result of a beta hepatic microsomal oxidation. The metabolites can be identified in urine in proportion of 70\% [17]. Clinical effects are more closely related to serum levels than to the administered dose, and clinicians can use therapeutic drug monitoring to optimize dosage decisions, in order to maximize efficacy and prevent toxicity [14].

When aiming to establish the efficient doses for valproic acid treatment, but also in the case of overdose or acute intoxication, it is important to monitor the serum levels of valproic acid due to its high hepatotoxicity potential, of which mechanism is still unknown. The hypothesis regarding the VPA hepatotoxicity from a biochemical standpoint includes hyperammonaemia, carnitine deficiency, pre-existing metabolism errors and the toxicity of its unsaturated metabolites present [27]. In the case of an overdose or of long-term treatment, high serum levels of hepatic enzymes and hyperammonemia may appear.

The plasma concentration of VPA higher than 100 $\mathrm{mg} / \mathrm{L}$ is concerning and a concentration higher than $450 \mathrm{mg} / \mathrm{L}$ is associated with a moderate or severe prognostic, although there is no tight correlation between plasma levels of VPA and the severity of clinical signs [24].

The need of an efficient management of patients under treatment with valproic acid led to the evolution of quick and accurate assays for anticonvulsants, of which, immunochemical methods are the most suitable. Immunochemical methods use a specific antibody for the tested molecule and a marked form of the same compounds. The introduction of a known quantity of antibody for a specific marked molecule and an unknown quantity of molecules to be analysed from a sample, will lead to the forming of two concurrent antibody-antigen complexes, one, with a labelled molecule, the other, with a molecule that will undergo analysis. The number of molecules marked by the antibody is inversely proportional to the number of initially unmarked molecules from the sample $[4,6,11]$.

There are two main ways to quantify the reaction: homogenous phase method and heterogeneous phase method. They require the separation of the bound forms from the free ones, as there is no difference between the signals produced by each of them. When the labelling is performed by an enzyme or a fluorophore, the measurement is made through an optical modification generated by a difference between the behaviour of the bound form and that of the free form $[6,11,21]$. The homogenous methods, faster and completely automatized are: Enzyme Multiplied Immunoassay Technique (EMIT) and Fluorescence Polarization Immunoassay Technique (FPIA).

In the EMIT method, the marking is made through an enzyme by binding the antibody to the labelled enzyme molecule. The introduction of an unmarked molecule (molecule to be tested) sets a part of the marked molecules free, which can then react with a substrate. The intensity of the reaction will be proportional to the quantity of molecules that are in the tested sample. Quantifying the enzymatic reactions if performed, usually, through optic scanning in ultraviolet $(340 \mathrm{~nm})$, by measuring the use of nicotinamide dinucleotide oxide $\left(\mathrm{NAD}^{+}\right)$which is a reaction cofactor [12].

The immuno-test reactive EMIT contains a specific substrate and a coenzyme. Only the free drug marked by the enzyme can act on the substrate, determining a conversion of the coenzyme. A change in light absorption which results is measured spectrophotometrically. It is the inactivation of the enzyme label that makes the EMIT principle unique; there is no need for subsequent separation of bound from unbound compounds, as with other immunoassays. EMIT is based on the competition between the molecule which will be determined (Ag) and the antigen marked with the enzyme, by occupation of the binding situs of the antibody [19].

Therapeutic serum concentration of VPA is between $50-100 \mu \mathrm{g} / \mathrm{mL}$ during controlled therapy but its toxic serum concentration may reach $120-150 \mu \mathrm{g} / \mathrm{mL}$. The aim of the study is to develop a quick, confident method of serum valproic acid determination by Enzyme Multiplied Immunoassay Technique (EMIT) and to describe its clinical applications.

\section{Materials and Methods}

\section{Materials}

In the laboratory, the VPA method was developed to determine serum valproic acid levels for the monitoring of treatment with valproic acid or to detect an acute intoxication with the substance. For determining serum levels of valproic acid on the VIVA Pro-E Siemens Analyzer, the EMIT method is used.

\section{Equipment}

The data shown in this material were obtained by using: an automated analyser: VIVA Pro-E SYSTEM, Siemens; a Vitros 650 and Kenolab system for the biochemical parameters determination; a EBA 200 Hetich centrifuge; automated pipettes: Eppendorf $1000 \mu \mathrm{L}$. 


\section{Reagents}

In order to verify the performance parameters, it was used the Emit ${ }^{\circledR} 2000$ Valproic Acid Assay reactive Kit from Syva ${ }^{\circledR}$, Siemens, kept in stability conditions $\left(2-8^{\circ} \mathrm{C}\right)$ and still in validity. The Kit contains:

R1 - Antibody/Substrate Reactive 1: mouse monoclonal antibodies reactive to valproic acid $(2 \mu \mathrm{g} / \mathrm{mL})$, glucoze-6-phosphate $(22 \mathrm{mM})$, nicotinamide adenine nucleotide (18 $\mathrm{mM})$, bovine serum albumin (BSA), preservatives and stabilizers.

R2 - Enzyme Reactive 2: Valproic acid marked with bacterial G6PDH $(0.39 \mathrm{U} / \mathrm{mL})$, Tris buffer, bovine serum albumin and its stabilizer, preservatives and stabilizers. The reagents were chosen as there is a protocol of adaptable work, offered by the producer, on the equipment utilized in this scope.

Methodology

In order to establish the certainty diagnosis in case of multidrug ingestion for suicidal purpose, the biological samples collected were processed according to specific laboratory procedures and analysed on the presented systems. The determination of the serum level of valproic acid was performed daily using the VPA method. The VPA method does not imply special environmental conditions. The reactions occurring during the measurement are performed on automated equipment with thermoregulation system. The working conditions are: $21 \pm 2{ }^{\circ} \mathrm{C}$ temperature and $40-60 \%$ humidity. The analyser was used by respecting the indications of the producer regarding daily and periodic maintenance.

Sample preparation

The serum samples were obtained in a centrifuge at $3000 \mathrm{rpm}$ for 3 minutes from the blood samples taken on vacutainers with anticoagulant (EDTA, heparin, citrate and oxalate/fluoride).

The biochemical parameters (serum ammonia, ALT and AST) were determined in the blood, for each day of admission in the ATI II Toxicology (Figures 2 and 3 ). The normal values for hepatic enzymes in the serum, ALT and AST, are between 10 - $45 \mathrm{U} / \mathrm{L}$ for ALT and 14 - $35 \mathrm{U} / \mathrm{L}$ for AST. The therapeutic serum levels of valproic acid are $50-100 \mu \mathrm{g} / \mathrm{mL}$ and the normal levels of ammonia in the blood are between 10 - $32 \mu \mathrm{mol} / \mathrm{L}$ (see Table V).

\section{Results and Discussion}

A 6-point calibration curve was drawn, using valproic acid calibrators, Emit ${ }^{\circledR}$ tox ${ }^{\mathrm{TM}}$ Syva. The calibration points are as follows: $0,10,25,50,100$ and $150 \mu \mathrm{g} / \mathrm{mL}$ and the values obtained are presented in Table I.

Table I

Results (dAbs/min) obtained from valproic acid calibrators, Emit ${ }^{\circledR}$ tox ${ }^{\mathrm{TM}}$ Syva measurements

\begin{tabular}{|c|c|c|}
\hline $\begin{array}{c}\text { Calibration } \\
\text { point }\end{array}$ & $\begin{array}{c}\text { Concentration } \\
(\boldsymbol{\mu} \mathbf{g} / \mathbf{m L})\end{array}$ & $\begin{array}{c}\text { Mean absorbance } \\
(\mathbf{d A b s} / \mathbf{m i n})\end{array}$ \\
\hline Level 0 & 0 & 0.2146 \\
\hline Level 1 & 10 & 0.2450 \\
\hline Level 2 & 25 & 0.2752 \\
\hline Level 3 & 50 & 0.3083 \\
\hline Level 4 & 100 & 0.3447 \\
\hline Level 5 & 150 & 0.3614 \\
\hline
\end{tabular}

For quality controls, we used BIO-RAD Liquichek ${ }^{\mathrm{TM}}$ for Therapeutic Drug Monitoring Control (TDM) with 3 levels of concentrations (Table II).

Table II

TDM control levels for valproic acid recommended by BIO-RAD Liquichek ${ }^{\mathrm{TM}}$

\begin{tabular}{|c|c|c|c|c|c|c|c|}
\hline \multirow{2}{*}{ Method } & \multirow{2}{*}{ Measuring unit } & \multicolumn{2}{|c|}{ Level 1 } & \multicolumn{2}{c|}{ Level 2 } & \multicolumn{2}{c|}{ Level 3 } \\
\cline { 3 - 7 } & $\mu \mathrm{g} / \mathrm{mL}$ & 32 & $23.7-40.2$ & 79.2 & $64.1-94.3$ & 124 & $104-144$ \\
\hline Valproic acid Emit 2000 & & Rean & Range & Mean & Range & Mean & Range \\
\hline
\end{tabular}

Applying a quality control Level 2 in the case of the VPA method indicates the fact that the standard deviation obtained by the laboratory is higher than that specified by the producer of the reactive kit (for example, out of 80 determinations, they obtained a mean $75.5 \mu \mathrm{g} / \mathrm{mL}$ with a standard deviation of 2.25 $\mu \mathrm{g} / \mathrm{mL}$ and a variation coefficient of $3 \%$ ).
The analysis of the quality control performed in the laboratory for the VPA method, we obtained an average value for TDM2 of $78.5 \mu \mathrm{g} / \mathrm{mL}$, with standard deviation of 7.1 and a coefficient of variation of $9 \%$ (Table III).

Table III

Summary statistics for TDM control BIO-RAD Liquichek ${ }^{\mathrm{TM}}$

\begin{tabular}{|c|c|c|c|c|}
\hline Control Bio-Rad TDM Liquichek $^{\text {TM }}$ & Mean & SD & CV & Points \\
\hline Level 1 $(\mu \mathrm{g} / \mathrm{mL})$ & 31.37 & 3.19 & 10.18 & 11 \\
\hline Level 2 $(\mu \mathrm{g} / \mathrm{mL})$ & 78.5 & 7.1 & $9.0 \%$ & 11 \\
\hline Level $3(\mu \mathrm{g} / \mathrm{mL})$ & 129.73 & 5.26 & $4.05 \%$ & 11 \\
\hline
\end{tabular}

This VPA method was used to determine serum valproic acid in the case of the multidrug overdose presented below. The samples were collected daily from the patient and the results are presented in Table IV. Because the VPA method is calibrated in the range 
$0-150 \mu \mathrm{g} / \mathrm{mL}$, dilution was required for the first two determinations. A 1:10 dilution was performed.

Table IV

Serum valproic acid levels $(\mu \mathrm{g} / \mathrm{mL})$ obtained by VPA method

\begin{tabular}{|c|c|}
\hline Sample number & Acid valproic level $(\boldsymbol{\mu g} / \mathbf{m L})$. \\
\hline 1 & 530 \\
\hline 2 & 320 \\
\hline 3 & 72 \\
\hline 4 & 56 \\
\hline 5 & 43 \\
\hline
\end{tabular}

Samples were collected after voluntarily ingestion of multiple substances with suicidal purpose (valproic acid, diazepam, sertraline, ethanol). The variation of biochemical parameters are depicted in Table $\mathrm{V}$. Blood samples are taken to perform a toxicological analysis, which reveals positive ethanol in blood, positive benzodiazepine and serum levels of valproic acid determined through the VPA method of 530 $\mu \mathrm{g} / \mathrm{mL}$. The time from ingestion to onset cannot be quantified by anamnesis data. Once absorbed, valproic acid is largely bound to plasma proteins and has a relatively small volume of distribution $(0.1$ to $0.4 \mathrm{~L} / \mathrm{kg})$ [30]. In the literature, a serum level $>450 \mu \mathrm{g} / \mathrm{mL}$ was more likely to be associated with a moderate or major adverse outcome. Under specific treatment it is found that already on the second day after hospitalization, the serum concentration of valproic acid decreased by half, and on the $5^{\text {th }}$ day after hospitalization it was within normal limits (Figure 1). Unfortunately, the concentrations of sertraline and diazepam could not be revealed, as only a quick one-use test for benzodiazepines was used, which came out positive. In a series of cases presented by Spiller et al. [27], patients with valproic acid concentrations above $450 \mu \mathrm{g} / \mathrm{mL}$ are more likely to develop significant clinical effects and have longer hospital stays $(\mathrm{p}<0.05)$.

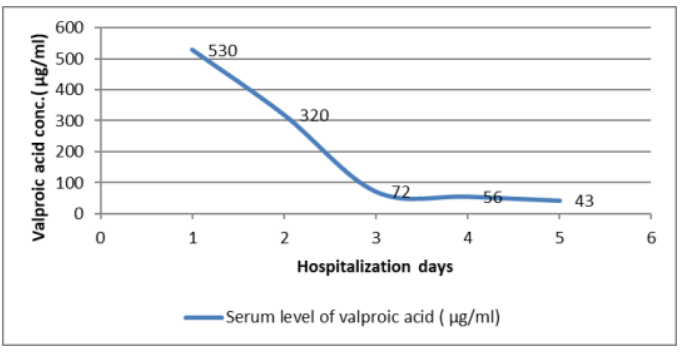

Figure 1.

The variation of valproic acid serum levels

Hyperammonaemia induced by VPA may be an important clinical consideration, especially when associated with liver disease or encephalopathy. The reported frequency of hyperammonaemia induced by VPA ranges from $16.2 \%$ to $83.3 \%$ [2, 9, 22, 23, 25]. Hyperammonaemia has been frequently reported in valproic acid ingestion and was found in 9 of the 10 patients in this series who had ammonia concentrations measured [24].

In our case, the biochemical determinations indicate hyperammonaemia (initially $77 \mu \mathrm{mol} / \mathrm{L}$ ) with the maximum value in the second day from admission $(255 \mu \mathrm{mol} / \mathrm{L})$, which correlate with the high level of valproic acid $(320 \mu \mathrm{g} / \mathrm{mL})$. In the $3^{\text {rd }}$ day from admission, under specific medical measures, the serum levels for valproic acid and ammonia were within normal limits (Figure 2 and Table V).

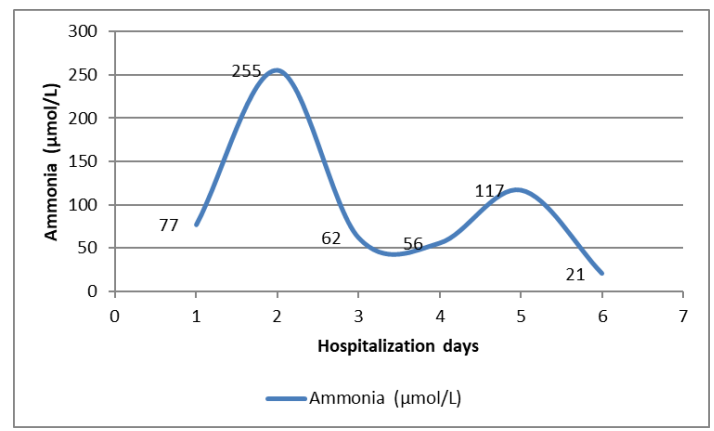

Figure 2.

The variation of ammonia serum levels

Paraclinically, severe hyperammonaemia (Figure 2), thrombocytopenia and hepatic cytolysis and pancreatic reaction are observed. Increases of serum amylases, ALT and AST were recorded. In the laboratory, no methods were available to detect sertraline, which can cause, alongside ethanol, rhabdomyolysis and hepatic cytolysis (high levels of $\mathrm{CK}$, in the following interval: 111 - $604 \mathrm{U} / \mathrm{L}$, with normal values at 55 $170 \mathrm{U} / \mathrm{L})[4,15,21]$.

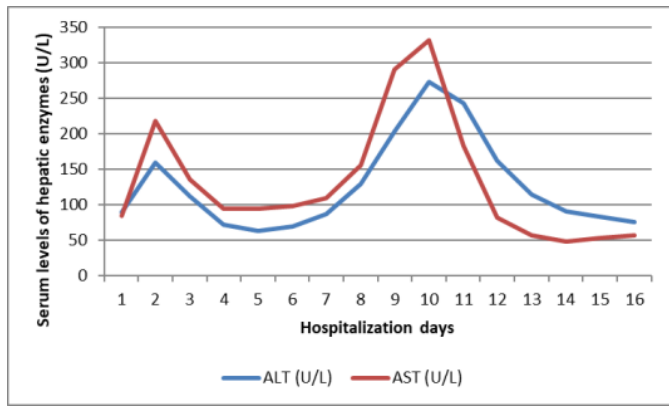

Figure 3.

The variation of hepatic enzymes, ALT and AST, during hospitalization

The biochemical determinations indicate an increase of serum levels of hepatic enzymes (initially $89 \mathrm{U} / \mathrm{L}$ ALT and $84 \mathrm{U} / \mathrm{L}$ AST) with the maximum values after ten days from admission (273 U/L ALT and 332 U/L AST) (see Figure 3). Seric amylases were mildly increased $230 \mathrm{U} / \mathrm{L}$, with a slow recovery from day 1 to day 15 . The course of pancreatitis was mild and responded well to medical conservative therapy. Serum electrolytes, creatinine, urea, APTT and glycaemia were all in normal range (Table V). 
The variation of biochemical parameters during hospitalization

\begin{tabular}{|c|c|c|c|c|c|c|c|c|c|c|c|c|}
\hline Day & $\begin{array}{l}\text { ALT } \\
(\mathrm{U} / \mathrm{L})\end{array}$ & $\begin{array}{c}\text { AST } \\
(\mathrm{U} / \mathrm{L})\end{array}$ & $\begin{array}{c}\text { Total } \\
\text { bilirubin } \\
(\mathrm{mg} / \mathrm{dL})\end{array}$ & $\begin{array}{l}\text { Creatinine } \\
(\mathrm{mg} / \mathrm{dL})\end{array}$ & $\begin{array}{c}\text { Amylase } \\
\text { (U/L) }\end{array}$ & $\begin{array}{l}\text { Glucose } \\
(\mathrm{mg} / \mathrm{dL})\end{array}$ & $\begin{array}{c}\mathrm{K} \\
(\mathrm{mmol} / \mathrm{L})\end{array}$ & $\begin{array}{c}\mathrm{Na} \\
(\mathrm{mmol} / \mathrm{L})\end{array}$ & $\begin{array}{c}\text { Urea } \\
(\mathrm{mg} / \mathrm{dL})\end{array}$ & $\begin{array}{c}\text { APTT } \\
\text { dry }\end{array}$ & $\begin{array}{c}\text { Ammonia } \\
(\mu \mathrm{mol} / \mathrm{L})\end{array}$ & $\begin{array}{c}\text { CK } \\
(\mathrm{U} / \mathrm{L})\end{array}$ \\
\hline 1 & 89 & 84 & 0.49 & 1.03 & 240 & 77 & 4.07 & 142.4 & 21 & 31.7 & 77 & \\
\hline 3 & 112 & 136 & & 1.26 & 240 & 155 & 3.44 & 142.1 & 48 & 31.1 & 62 & \\
\hline 4 & 72 & 94 & 1.24 & 0.88 & 230 & 391 & 2.65 & 131.4 & 48 & 28.3 & 56 & \\
\hline 7 & 87 & 109 & 3.07 & 0.71 & 205 & 132 & 4.09 & 142.6 & 61 & 25.9 & 21 & \\
\hline 8 & 130 & 156 & 2.66 & 0.71 & 194 & 255 & 3.79 & 137.7 & 44 & 27.2 & & 127 \\
\hline 9 & 203 & 291 & 2.83 & 0.72 & 173 & 158 & 4.00 & 138.8 & 61 & & & \\
\hline 10 & 273 & 332 & 1.68 & 0.63 & 165 & 109 & 3.36 & 141.1 & 66 & 28.5 & & \\
\hline 11 & 243 & 183 & & 0.63 & 120 & 142 & 4.48 & 136 & 37 & & & \\
\hline 16 & 76 & 57 & 1.07 & 0.61 & 56 & 85 & & 136.7 & 24 & 29.0 & & \\
\hline Range & $10-45$ & $14-35$ & $0.3-1.3$ & $0.70-1.30$ & $23-85$ & $74-106$ & $3.5-5.1$ & $136-145$ & $13-43$ & $24-36.5$ & $10-32$ & $55-170$ \\
\hline
\end{tabular}

The results obtained for the verification of the EMIT technique using the commercial kit show these values were obtained in the laboratory by averaging a relatively low number of determinations, but yet they are within the confidence interval. Despite the fact that valproic acid is an old generation antiepileptic drug, in the literature, there is little information about the case series of VPA overdose.

The therapeutic concentration of serum valproate is considered $50-100 \mathrm{mg} / \mathrm{L}$. Yet there are clinical studies revealing toxicity signs below the therapeutic levels, but also patients who necessitated increased plasmatic concentrations to achieve clinical efficacy. The relations between the daily dose and serum concentration of valproic acid are also multifactorial [20, 22]. Significant predictors influencing VPA pharmacokinetics are body weight, VPA dose, concomitant medications, gender or age, but still there is an important interindividual variability ranged from 13.40 to $35.90 \%$ [23].

The relation between serum VPA and biochemical levels of hepatic enzymes, amylase and ammonia is also conflicting. Hepatotoxicity and non-alcohol fatty liver disease is correlated to chronic moderate increase of valproic acid concentration, but there is an important individual variability [4, 28].

In an analysis by Chicharro et al., 22 of 24 studies reported an association between serum ammonia levels and serum concentrations, or doses, of VPA [5, 29]. However, a study by Ando, et al. showed no significant correlation between serum VPA and ammonia levels [1]. In the presented case, we also found a good correlation between the dynamics of serum valproic acid and hyperammonaemia [18, 29].

The clinical signs of acute overdosing include, usually, muscular hypotonic coma, hyporeflexia, myosis, respiratory dysfunctions, metabolic acidosis, arterial hypotension and collapse/circulatory shock [24].
Acute pancreatitis is a rare complication estimated at $1.4-1.6 \%$, varying in intensity from mild to severe, with haemorrhagic necrosis and death [10, 20]. Clinically evocative signs are abdominal pain in the upper floor, nausea, vomiting, loss of appetite and biological confirmation is given by increased amylase and serum lipase. The onset of acute pancreatitis depends more on serum concentration than on the administered dose. Valproic acid circulates bounded by serum proteins. At concentrations above $87 \mathrm{mg} / \mathrm{L}$, the free valproate can become toxic. The etiological mechanisms of pancreatic damage are incompletely elucidated, but several factors have been incriminated: reduced carnitine, increased fatty acid levels, deficiency in mitochondrial metabolism with accumulation of toxic products, depletion of free radical scavengers (catalase, superoxide dismutase, glutathione peroxidase) leading to an excess of free radicals, with increased endothelial permeability and lipid peroxidation [10].

The unpredictable and unfavourable connection of dose and plasma concentration of valproic acid supports the necessity to regularly measure its plasma concentration. Careful attention must be applied to specific gender and particular age group on an individual basis in the interpretation of plasma concentration results, in order to facilitate the modification of doses and develop the best approach in treatment and to obtain the desired clinical response, because multiple factors can affect the valproic acid plasma concentration.

\section{Conclusions}

The EMIT method is an optoelectronic method which, through optical scanning in UV at $340 \mathrm{~nm}$, quantifies the enzymatic reaction.

The VPA method can be applied confidently to determine the serum levels of valproic acid, being a 
relatively precise and exact method. The small number of serum samples used in the EMIT is a distinct advantage over other methods, especially in paediatric medicine.

Also, the method is quick, the result being obtained within minutes from introducing the sample in the analyser, and it is useful both in monitoring valproic acid treatment and, especially, in establishing a certain diagnosis in acute mono or polydrug acute intoxications.

The limitations of the method are those related to the field of measurement of serum valproic acid concentrations. Because it is calibrated in the range $0-150 \mu \mathrm{g} / \mathrm{mL}$, in case of overdoses successive dilutions must be made (in our case 1:10).

Determining serum levels of valproic acid in the case of acute intoxications is important both in establishing a certainty diagnosis, but also, especially, in rapid and correctly applying medical measures. The method is also useful in monitoring the serum concentration of valproic acid in patients with chronic treatment, as plasmatic concentration can also increase to toxic levels in case of metabolic disturbances. To increase the clinical benefit, EMIT determination of valproic acid must be interpreted in correlation with biochemical parameters

\section{Conflict of interest}

The authors declare no conflict of interest.

\section{References}

1. Ando M, Amayasu H, Itai T, Yoshida H, Association between the blood concentrations of ammonia and carnitine/amino acid of schizophrenic patients treated with valproic acid. Biopsychosoc Med., 2017; 11: 1-8.

2. Arbune A, Craiu D, Cuciureanu ID, Iulian C, Pavel LL, Berbece IS, Grigore CA, Dulamea A, Challenges of valproate treatment during pregnancy: Pros and cons. Rev Chim., 2020; 71(2): 456-459.

3. Asghar MA, Rehman AA, Raza ML, Mumtaz N, Asghar MA, Shafiq Y, Khan K, Prescription pattern of antiepileptic drugs in southern Pakistan: A retrospective cohort study in tertiary care centres. Farmacia, 2019; 67(6): 1091-1098.

4. Ben-Cherif W, Dridi I, Aouam K, Ben-Attia M, Reinberg A, Boughattas NA, Circadian variation of valproic acid pharmacokinetics in mice. Eur $J$ Pharm Sci., 2013; 49(4): 468-473.

5. Chicharro AV, De Marinis AJ, Kanner AM, The measurement of ammonia blood levels in patients taking valproic acid: Looking for problems where they do not exist?. Epilepsy Behav., 2007; 11: 361-366.

6. Darwish IA, Immunoassay methods and their applications in pharmaceutical analysis: Basic methodology and recent advances. Int J Biomed Sci., 2006; 2(3): 217-235.

7. Farinelli E, Giampaoli D, Cenciarini A, Valproic acid and nonalcoholic fatty liver disease: a possible association?. World Hepatol., 2015; 7(9): 1251-1257.
8. Habhab SF, Ulvin LB, Taubøll E, Svalheim S, Olsen $\mathrm{KB}$, Horn MA, Heuse K, Influence of valproateinduced hyperammonemia on treatment decision in an adult status epilepticus cohort. Epilepsy Behav. 2020; 111: 1-4.

9. 9.Haidukewych D, John G, Zielinski JJ, Chronic valproic acid therapy and incidence of increases in venous plasma ammonia. Ther Drug Monit., 1985; 7(3): 290-294.

10. Jain A, Haque I, Tayal V, Roy V, Valproic acidinduced acute pancreatitis. Ind J Psychiatry, 2019; 61(4): 421-422.

11. Ionică $\mathrm{M}$, Optoelectronic methods for determining xenobiotics incriminated in acute intoxication or contamination of the population and personnel involved in industrial processes. $\mathrm{PhD}$ thesis, Politehnica University, Bucureşti, 2009.

12. Karch SB, Drug Abuse Handbook, Ed. Boca Raton, FL: CRC Press LLC, 1998.

13. Loscher W, Valproate: A reappraisal of its pharmacodynamics properties and mechanism of action. Progr. Neurobiol., 1999; 58: 31-59.

14. Macovei R, Danescu I, Caragea G, Ionica M, Valproic acid poisonings: An old and new concern, XXXII International Congress of the European Association of Poison Centres and Clinical Toxicologists, 28 31 may, 2013, Copenhagen, Denmark. Clin Toxicol., 2013; 50(4): 315

15. Maramattom B, Thomas J, Kachlare N, Sertralineinduced reversible myopathy with rhabdomyolysis and trismus. Neurology India, 2018; 66(1): 235-237.

16. Methaneethorn J, A systematic review of population pharmacokinetics of valproic acid. Br J Clinic Pharmacol., 2018; 84(5): 816-834

17. Nau H, Loscher W, Valproic acid and metabolites: Pharmacological and toxicological studies. Epilepsia, 1984; 15(Supl 1): 14-22.

18. Nussbaum LA, Hogea LM, Folescu R, Grigoras ML, Zamfir CL, Boanca M, Erdelean D, Rosca ECI, Nussbaum L, Simu MA, Lupu V, Biochemical modifications study of cerebral metabolites by spectroscopy in epilepsy treatment. Rev Chim., 2018; 69(4): 965-970.

19. Pieper And Rutledge, Laboratory Techniques for Pharmacists, Upjohn 1989; pg. 40, figure 12, www.boomer.org.

20. Quan W, Shao Q, Zhang H, Liu FH, Zhang XH, Acute pancreatitis associated with valproate treatment. Chin Med J (Engl), 2018; 131(15): 1889-1890.

21. Rebollo N, Calvo MV, Martín-Suárez A, DomínguezGil A, Modification of the EMIT immunoassay for the measurement of unbound mycophenolic acid in plasma. Clin Biochem., 2011; 44(2): 260-263.

22. Savlovschi C, Serban D, Andreescu C, Dascalu A, Pantu H, Economic analysis of medical management applied for left colostomy. Chirurgia, 2013; 108(5): 666-669.

23. Sharma S, Galati S, Kabra M, Blood ammonia levels in epileptic children on 2 dose ranges of valproic acid monotherapy: a cross-sectional study. J Child Neurol., 2011; 26: 109-112.

24. Spiller HA, Krenzeloc EP, Klein-Schwartz W, Multicenter case series of valproic ingestion: serum 
concentration and toxicity. J Clin Toxicol., 2000; 38: 755-760.

25. Socea B, Carap A, Bratu OG, Diaconu C, Dimitriu M, Socea LI, Bobic S, Constantin VD, The role of the composite and biologic meshes in the trocar site hernia repair following laparoscopic surgery. Revista de Materiale Plastice, 2018; 55(2): 146-148.

26. Suen CF, Boyapati R, Simpson I, Dev A, Acute liver injury secondary to sertraline. BMJ Case Rep., 2013; 9: bcr2013201022

27. Voicu V, Macovei R, Miclea, Diagnosis and treatment in acute poisonings. Brumar Publishing House, Timişoara, 2006.
28. Walker CP, Deb S, Rhabdomyolysis and hepatotoxicity from valproic acid: Case reports. J Pharm Pract., 2019; 1-5.

29. Wu MY, Chang FY, Ke JY, Chen CS, Lin PC, Wang TS, Valproic acid-induced hyperammonemic encephalopathy in a patient with bipolar disorder: A case report. Brain Sci., 2020; 10(3): 187-193.

30. Zaccara G, Messori A, Moroni F, Clinical pharmacokinetics of valproic acid. Clin Pharmacokinet., 1988; 15(6): 367-389.

31. Zhu MM, Li HL, Shi LH, Chen XP, Luo J, Zhang ZL, The pharmacogenomics of valproic acid. J Hum Genet., 2017; 62(12): 1009-1014. 